Marie Roubalová, Roman Králik, Natalia A. Zaitseva, George S. Anikin, Olga V. Popova and Peter Kondrla

\title{
Rabbinic Judaism's Perspective on the First Crimes Against Humanity ${ }^{1}$
}

\section{Prvi zločini proti človeštvu z vidika rabinskega judo- vstva}

Abstract: This article focuses on the first recorded crimes (sins) against humanity in the context of the broader and more fundamental issue of human life's intrinsic value and dignity. An analysis of the views of rabbinic Judaism reveals a network of concepts that are dynamically intertwined. They originate from a strictly monotheistic framework (worldview) of Judaism that helps resolve whether a person is allowed to end his life for the sake of others. Careful analysis and interpretation of the first three acts of violence recorded in the Hebrew Bible (Tanakh) reveal the catastrophic consequences of choosing to end another's life without considering its intrinsic value while ignoring the intrinsic value of the other and his dignity and assuming that humans have the power to decide the fate of another human being, to distance humanity from God (from God's presence), trapping humans in the idolatry of materialism. Moreover, the Hebrew Bible (Tanakh) allows for a factual assessment and distinction between different acts of violence. It offers guidance, protection, and hope, for both victims and perpetrators, in the drama of creation and salvation.

Keywords: rabbinic Judaism, crimes against humanity, sin, murder, Cain, Abel, the value of human life, Hebrew Bible (Tanakh)

Povzetek: Članek se osredotoča na prve zabeležene zločine (grehe) proti človeštvu v kontekstu širšega in bolj temeljnega vprašanja notranje (intrinzične) vrednosti in dostojanstva človeškega življenja. Analiza pogledov rabinskega judovstva

1 This article was published with the support of the Slovak Research and Development Agency under contract No. APVV-17-0158 - Constantine the Philosopher University in Nitra, the Kazan Federal University Strategic Academic Leadership Program, Russian Academic Excellence Project 5 - 100 of the I M Sechenov First Moscow State Medical University (Sechenov University), the Program of Development of Financial University under the Government of the Russian Federation for 2020. The correspondent author of the article is Roman Králik(RUDN University). 
razkriva mrežo pojmov, ki so dinamično prepleteni. Izvirajo iz strogo monoteističnega okvira (pogleda na svet) judovstva, ki pomaga razreševati vprašanje, ali je človeku dovoljeno, da konča svoje življenje zaradi drugih. Skrbna analiza in interpretacija prvih treh dejanj nasilja, zabeleženih v hebrejski Bibliji (Tanak), razkriva katastrofalne posledice izbire končanja življenja drugega, ne da bi pri tem upoštevali njegovo notranjo vrednost. Medtem sta neoziranje na intrinzično vrednost drugega in na njegovo dostojanstvo in predpostavljanje, da imamo pristojnost, odločati o usodi drugega človeka, oddaljili človeštvo od Boga (od božje navzočnosti) in ga ujeli v past malikovanja materializma. Še več, hebrejska Biblija omogoča stvarno oceno in razlikovanje med različnimi dejanji nasilja. Zagotavlja vodstvo, zaščito in upanje, tako za žrtve kakor tudi za storilce, v drami stvarjenja in odrešenja.

Ključne besede: rabinsko judovstvo, zločini proti človeštvu, greh, umor, vrednost človeškega življenja, Kajn, Abel, hebrejska Biblija (Tanak)

\section{Introduction}

Humans tend to consider their lives to be the most valuable thing in the world. However, human life itself does not have the highest value. Rabbinic Judaism recognizes three other categories that exceed the value of human life: (1) believing in the existence of one God; (2) protecting the lives of other human beings; and (3) maintaining the purity of sexual intercourse (BT, Sanhedrin 74a). A person who is forced to disobey one of these commandments (e.g., he/she is forced to convert, to murder another human being, or participate in a forbidden sexual act) is allowed to end his life either by committing suicide or by letting his friends or enemies end his life. A death like this is called "Kiddush Hashem - sanctification of God's Name« (Zozulak and Valčo 2018, 1037-1050). Rabbinic Judaism accepts an unnatural ending of human life only in the situations mentioned above. The most intriguing question is whether a person should be allowed to end his own life for the sake of others. One group of rabbis strongly supports the idea that this is possible only under specific circumstances. In contrast, another group is convinced that a person should never be allowed to do so (Lamm 2007, 139). Cases in which one's life and the lives of one's relatives must be protected need further discussion.

Every human being is considered a relative (or, in religious terminology, , a neighbor ") because we all have one common ancestor - Adam. Besides, all humans have been created in God's image (imago Dei), ${ }^{2}$ which gives them a stamp of eternal value and destiny (Zozulak and Valčo 2018, 1037-1050). Therefore, deep respect and protection of human life are natural and expected for everyone and should not be considered a subjective or national matter only. Tanakh (the most

2 Christian exegetes would interpret this passage christologically in a Trinitarian fashion in which ,imago $D e i^{\prime}$ is understood as, imago Trinitatis (Valčo et al. 2019, 176-192). 
famous and most-cited form found in Decalogue $)^{3}$ directly forbids putting human life in danger. Hence it directly opposes murder and killing and forbids a believer to commit murder.

A mythopoetic description of the first three acts of violence is mentioned at the beginning of Tanakh (in the third and fourth chapters of Bereshit). These acts of violence occurred in the First, Second, and Seventh generations of humankind. The three acts of violence drew humankind apart from God (God's Presence) (Kardis 2019,121$)$, trapping them in a materialistic civilization. To recover a clear notion of justice and sanctity, including a sense of mutual dependency and solidarity, an intentional, carefully designed system of conducive environments, education, and upbringing need to be implemented in the lives of communities of believers (Šoltés 2018, 81-90; Vansač and Gulašová 2018, 216-225).

\section{The first intentional murder - a choice between life and death}

The first intentional murder mentioned in Bereshit is Cain's murder of his brother Abel. However, long before the first murder, there had been an attempt to put human life in danger. Nachash, the speaking serpent (Targum and Midrashim perceived as the angel of death Samael (Targum Pseudo-Jonatan; Bereshit 3,6)), threatened human life in the Garden of Eden for the first time. Snakes were considered to be the most intelligent animals. Having promised deep knowledge to Eve, the serpent deceived her into eating the forbidden fruit from the Tree of Knowledge of Good and Evil, even though consumption of the fruit was punishable by death. The consumption of the forbidden fruit, as mentioned in Midrash, is the main reason why death came to take Adam, Eve, and all their offspring (Bereishit Rabbah 16,6). According to Rabbinic Judaism, humans were created immortal. Ideas mentioned in Bereshit, however, do not support this claim. Bereshit also states that after Eve had eaten the forbidden fruit, God decided to prevent humans from eating fruits from the Tree of Life. The fruit from the Tree of Life represents immortality ( $G n 3,22-24)$. The sacred text does not mention an immediate death after consumption of the forbidden fruit. However, it is stated that humans remain mortal $(3,19)$. Rabbis think that humans became mortal only after eating from the Tree of Knowledge. When the Israelites were given Torah on Mount Sinai, they were also given back their immortality. However, the sin of worshipping the Golden Calf divested them of their newly-received immortality, and they became mortal once again (Shemot Rabbah 32,1). Rabbis claim that the Torah represents and supports life in general but disobeying one of the commandments ultimately leads to death. Adam and Israel lost their immortality because they decided to disobey the Torah.

3 For a treatment of Talmudic literature on relevant topics see Slivka 2018, 37-44. 


\section{The first fratricide - a choice between good and evil}

The first fratricide happened in the Second Generation. It is mentioned in the fourth reading of Bereshit. This reading can be divided into four parts: (1) Gn 4,16: the story of Cain and Abel, (2) Gn 4,17-22: Cain's genealogy, (3) Gn 4,23-24: Lamech's poem, which is presumably a part of a longer poem, (4) Gn 4,25-26: Appendix about Sethand Enosh. ${ }^{4}$

Some of the ideas mentioned above remain unclear, however: "No one can claim to be able to explain these parts with absolute certainty. " (Žák 1990, 66) When studying the chapter, rabbis uncovered new aspects and ideas (see below) that became the subject of follow-up analyses worked out in the form of commentaries. The analyses are focused on the following aspects: (1) The aspect of the Law: Crime and punishment; (2) The aspect of humanity: Humankind, Fraternity, Mutual responsibility, and dependency; (3) The aspect of ethics: Good and evil; (4) The theological aspect: Sin, atonement, redemption; (5) The didactic aspect: Acceptance and rejection of a child; (6) The psychological aspect: Man's character and variability of human characters. Animal impulses in humans; (7) The mystical aspect: secrets that a rational approach cannot uncover.

Composed of the mentioned elements, the Biblical narrative is a narrative about the rise of human civilization and humanity's adaptation to the world after being banished from the Garden of Eden. The author (or an editor) interconnected it with the first chapter of the Book of Bereshit. Bereshit contains the Creation myth describing the Seven days of Creation. The fourth chapter of Bereshit narrates about the Seven Generations that gave birth to human civilization. The peaceful life of humanity in the Garden of Eden is forever lost. Humans now must face struggles, danger, and violence.

The civilized world gradually developed (or decayed according to some) because of farming (Cain), herding (Abel, Jabal), city culture (Cain, Enoch, Irad), metallurgy (Tubal-Cain), music (Jubal), and faith (Enos). As shown below, some rabbis have promoted the idea that civilization's early development was also supported by the first human sovereign (Lamech), prostitution, and sacred prostitution (Naamah). The author of the scripture claims that humankind played a crucial role in developing the civilized world. This view contrasts with other nations' belief that developing civilized world results from help and support from deities.

The most noticeable aspect of the narrative is its smooth development (or changes) in the way of life of humans, walking' and later ,sitting'. The former , walking human' (gatherer and shepherd) became a , sitting human' (a farmer who settled in one place). The connection between these two lifestyles increased human prosperity in the world. Farmers feed their cattle with crops, and the cattle fertilize fields. Humans grow richer; they build cities, develop culture and faith. Humankind inevitably becomes a slave to wealth and money. A settler (a man who settled in one place) is the stronger one (Cain survives); however, the nomadic

4 Seth replaced deceased Abel. Midrashim states that (Numbers Rabbah 14,20). 
type (deceased Abel) will always represent the archetype of the original human lifestyle.

The history and traditions of shepherds and farmers are interconnected (Skolnik and Berenbaum 2007). The fourth chapter of the Book of Bereshit (describing the conflict between Cain and Abel) presumably contains two layers reflecting the lifestyles mentioned above. The story of Cain and his offspring is a part of the older scripture that talks about nomadic Cainite people, their forefather Cain and the first ancient murder (see the fragment of the ancient poem of Lamech) that cursed them to become settlers and bound them to one place. The murder of Abel is a part of a more recent scripture (because the author of the text had already known the story told in the second and the third chapter of the Book of Bereshit). However, the editors of Tanakh provide the reader with separate stories, and this is how the text has been interpreted and commented on for many rabbinic generations.

\subsection{The second generation}

The story of the first fratricide begins with Adam meeting Eve for the first time. The word ,jada' (to know) includes both mental and physical knowledge. However, the word used in this context is also a euphemism for sexual intercourse between men and women. In this very context, the verb ,to know' refers to ,conceive' and ,give birth'. ${ }^{5}$ Rashi (Bereshit 4,1.) believes that Adam knew his wife Eve before they disobeyed God, i.e., before they were banished from the Garden of Eden. Other rabbis suppose that he knew her for the first time after being banished from the Garden (Yad David). Eve gave birth to her first son Cain (Gn 4,1a). She delivered her child in the Garden of Eden (Rashi, Bereshit 4,1. Hirsch, Bereshit 4,1.).

Eve was happy that she gave birth to a baby boy. Her son Cain was another man in a hard-working family that cultivates the land for living, representing hope for a better and more comfortable future in which he will be able to help his father with »his work under the sun « $(\operatorname{Eccl} 2,22)$. We can see the same happiness and sense of joy in the words of Noah's father after Noah was born. His father hopes that the baby boy will make the living easier for his family: „Truly, he will give us rest from our trouble and the hard work of our hands, because of the earth which was cursed by God.« (Gn 5,29b)

The firstborn son was keenly awaited because, in the future, he would take care of his old parents and be the successor of his father's work, and he will continue to carry the family values and traditions. Every baby boy was a long-awaited saviour who would crush the head of the serpent $(3,15)$. However, the exact expectations are associated with the birth of a baby girl because she may be the one who will finally give birth to another man in the family.

Midrashim states that she conceived by a miracle and gave birth immediately (Bereishit rabbah 22,2). 
Eve is just as happy as a man who saw his wife for the first time. ${ }^{6}$ Cain's act of violence would be perceived as disappointing as his mother's consumption of the forbidden fruit. Eve expressed her great expectations and hoped that she immediately put them into her newborn son after giving birth $(4,1 b)$. However, translating this short and clear sentence is not an easy task to do. Von Rad claimed that it is hard to translate each word of the sentence and keep its meaning (Rad 1972, 103). The main difficulty with the translation is that there are various possibilities to translate the words "kaniti ish et Adonai» in the sentence, each of them producing a different meaning.

According to commentaries, Eve expressed her gratitude for the newborn son, for she thought she had given birth to a Messiah (or God's angel). Unfortunately, she was holding the first murderer in the history of humankind. However, at that moment, she was nothing more than a mother holding her innocent child-the child she and her husband would raise and take care of for many years.

Later, Eve gave birth to another baby boy named Abel (Gn 4,2a) - Cain's brother. The social status of a younger child is expressed in the following verse: «in pain you shall bring forth children, yet your desire shall be for your husband [Gn 3,16]." (Prudký 2018, 224) The text, however, does not mention whether Adam ,knew' her wife once again before the birth of Abel (it only mentions that she "gave birth again « or in a literal translation, "she added one birth «). Based on this statement, many rabbis think that Cain and Abel were twins (Pirkei DeRabbi Eliezer 21). The text also does not mention any expectations or hopes put into Abel.

\subsection{Cain's and Abel's occupation}

Adam and Eve's children are put into a more challenging life position than their parents originally had been. They must deal with demanding circumstances in stark contrast to the Garden of Eden's ideal life. As was already mentioned, these two men represent archetypes of settlers (farmers) and nomads (shepherds). Tanakh, however, does not depict farming as an inferior lifestyle. Adam is the very first farmer who has to take care of and protect the Garden. Since this moment, Jews have been longing to have their land that was promised to their forefather Abraham. Even though Adam was a farmer, the classical and archetypal lifestyle is not considered farming neither hunting, but herding (Žák 1990, 70; Beneš and Vad'ura 2010, 118). It is also important to mention that the text of Tanakh does not label farming as evil; neither does it mark herding as good, nor does it differentiate specifically between these two. One brother cultivates land on which the other brother shepherds his cattle.

Since Cain was the firstborn, he followed his father's footsteps and became a farmer just as he was predestined to do. In the Hebrew scripture, he is called ithe one who slaves (serves) the land " or "slave of the land " (Beneš and Vad'ura 2010, $114 ; 118)$. Cain does exactly what his parents, having been banished from the

"This is now bone of my bone and flesh of my flesh: let her name be Woman because she was taken out of Man. « $(G n$ 2,23) 
Garden of Eden, were commanded to do by God - he works hard to feed himself and his family. The cultivated land called , adama' resembles the first man Adam, who has to cultivate land to survive. They work hard on the land cursed by God. Cain takes an example from his father's diet as well. He primarily eats plants because God forbade killing God's creatures and consuming their flesh (Rashi, Bereishit 1,29.): "See, I have given you every plant yielding seed that is upon the face of all the earth, and every tree with seed in its fruit; you shall have them for food." (Gn 1,29) Since the two brothers did not sin until that time, some propose that Cain cultivated soil free of God's curse and lived according to the words of God. Another perspective considers the possibility that their parents' sin may have cursed the land cultivated by their children. The strong Cain (unlike the weak Abel) is not afraid of God's curse on the land. He decides to try and break it with his strength. Midrashim mentions that he became obsessed with cultivating the cursed soil, hence growing further from God (Bereshith Rabbah 22,6.). There is a resemblance to his mother, who became obsessed with the forbidden fruit in the Garden of Eden after meeting the serpent.

The second son, Abel, became a shepherd (4,2b). His occupation, too, is connected to past circumstances. However, it is not as obvious. He produced animal fur that served as clothing for humans to protect them from cold (when humans were not allowed to eat animal flesh). Abel provided clothes to his parents and, therefore, followed God's example, who gave them clothes after they had realized they were naked $(3,21)$. Rashi (Bereishit 4,2) thinks Abel chose this occupation because he wanted to be as distant from the cursed soil as possible (unlike his brother Cain). He feared the curse. However, many people associate this occupation with a meat diet allowed by God only after the Great Flood $(9,3)$. Rabbis were deeply concerned about this fact. Therefore, they emphasized that the only animal products Abel used were animal skin, milk, and wool, but never meat (Mizrachi, Bereishit 4,2).

\subsection{The first attempt to gain God's favour - the first sacrifice}

Working and serving God have always been connected because a human being can offer nothing more to God but his servitude. In the past, the figure of a father represented a sacrifice. However, as we see, it is not applied in this case. The main participants of the sacrifice are the two brothers. Products of their work are presented to God as a sacrifice. This type of sacrifice is called ,mincha' (,additional sacrifice/a gift') in Hebrew. The word ,mincha' is also used for a king's gift to win his favour (Dubovský 2008, 195). The word ,mincha' mentioned in the following chapters of Tanakh expresses gratitude and dependency on God (most frequent are plant products). Cain presented God with a sacrifice that came from land cultivation (Gn 4,3). Abel offered God his firstborn sheep and their fat $(4,4 a ;$ Lv 3,16; Lv 7,23; Lv 7,25).

God, however, accepted (,looked at it'; ,gave attention') Abel's sacrifice and refused Cain's sacrifice (,did not look at it'). How the two brothers found out about the acceptance and refusal of their sacrifice is unclear from the scripture. God did 
not communicate with them directly about his decision. When translating the Bible from Hebrew to Greek, translator Theodore decided to use the verb "set on fire« (Jb, 1,16). He assumes that God set Abel's sacrifice on fire because he accepted it, and as a sign of refusal, he left Cain's sacrifice unnoticed (Dubovský 2008, 195). The same idea is mentioned in Midrashim, and Rashi supports this explanation as well (Bereishit Rabbah 22,10; Midraš Zuta 35; Raši, Bereishit 4,4). The acceptance and refusal of sacrifice may as well be linked to God's approval and disapproval of their occupations (Mrázek 1989, 31).

Rabbi Hirschensohn sees things differently. He believes that the first real sacrifice (as we understand it today - on the altar) was offered to God for the first time by Noah (Drazin 2014). Noah's Ark sheltered humans and animals, and God did not allow these animals to be eaten. After surviving the flood, humans kill animals saved from death on Noah's Ark without any reasonable explanation. God smelled the burned flesh of animals and said: "/ will never again curse the ground because of humankind, for the inclination of the human heart is evil from youth; nor will I ever again destroy every living creature as I have done. " $(G n 8,21)$ Every sacrifice (even the temple sacrifice) is nothing more but a way for people to get closer to God and express gratitude to Him. The same compromise is later made by God himself when he approves eating meat (a diet which is typical for carnivores), even though it was never his plan in the first place. Cain and Abel (according to Hirschensohn) did not build altars, they did not slit throats of cattle as a part of the sacrifice, and they did not burn their offerings. It was better to offer God a living creature than its dead body. The two brothers brought their sacrifice to a specific place (either a mountain or to the entrance of the Garden of Eden) and left it there. Cain's sacrifice remained untouched by God, and he thought, mistakenly, that God did not accept it. Animals brought to one of the places mentioned earlier ran away as soon as Abel had left, and he, again mistakenly, thought it was a sign of God's acceptance (Drazin 2014).

The acceptance of Abel's sacrifice is one of many cases mentioned in Tanakh when the second brother is shown more favour than the firstborn. The Torah, however, does not provide us with any reasonable explanation for God's decision. This fact has been discussed for centuries, and opinions vary: "However, it is assumed that God is always fair, and humans understand his decisions. "(Prudký $2018,239)$ Rabbis think that the main reason for God's decision lies in the type of sacrifice and its purpose.

According to most rabbinic tradition, the difference may be either in the quality of sacrifice or the man who presented it, ${ }^{7}$ in its quantity ${ }^{8}$ or the form of consumption of the sacrifice (239). When it comes to sacrifice quality, rabbis cannot agree on what should be considered the best sacrifice. Their opinions differ: it

"By faith Abel offered to God a more acceptable sacrifice than Cain's. Through this he received approval as righteous, God himself giving approval to his gifts; he died, but through his faith he still speaks." ( $\mathrm{Hb} 11,4)$

8 The first sacrifice was offered by Cain; Abel saw it and he presented God with greater offering. Josephus Flavius though Abel was close-fisted (Antiquitates Judaeorum I 2,1). 
could be things such as the firstborn animal from the herd, an animal (better than a plant), Paschal lamb (better than a plant or any other animal), anything valuable, things of a natural origin (better than products linked to land cultivation), substitute sacrifice or a sacrifice for redemption (better than any other type of sacrifice). When differentiating between men who presented a sacrifice, the focus may be on their physical qualities, moral qualities, social status, origin, or intentions. One of these may be why the scripture mentions that God looked only at Abel's sacrifice and did not look at Cain's sacrifice or that he (God) paid attention only to Abel while ignoring Cain.

Some rabbis come with a different perspective. They think that there is no reason at all for God's actions (the secret of the chosen one) (Rad 1972). God is the ultimate authority, and he is free to act as he wishes, just as he, later on, explains to Moses: "I will have mercy on whom I will have mercy, and I will have compassion on whom I will have compassion.« (Ex 33,19)

Cain did not get offended by God for not accepting his offering; however, he got angry with Abel. To be more specific, it seems that Cain got envious of his brother. Midrashim tries to provide a few other possible reasons for Cain's anger and the murder. The explanations are based on three aspects (Leibowitz 2004, 39): (1) Material aspect (an argument focused on their parents' heritage ${ }^{9}$ or division of the world; (2) Sexual aspect (a dispute about a woman - mother or a sister); (3) aspect of belief (future of the world, placement of the Temple, the ultimate authority and the purpose of humankind). Another possible explanation is that there can be no reasonable explanation for the argument between the two brothers. It seems that the question of why a human being is willing to kill another will remain unanswered.

\subsection{Events before the murder}

Cain's sacrifice was overlooked by God, as we read: »but for Cain and his offering he had no regard. So, Cain was furious, and his countenance fell." $(G n 4,5)$. The expression that consists of words "set on fire" - ,chara' and "a lot " - ,meod" (as can be seen in this case) or the infinitive used in Tanakh, express a state of mind that leads a man to the worst action (usually murder) (Gn 4,5; 34,7; Nu 16,15; 1 $S 18,8$.). Some rabbis, however, support the opinion that ,chara le' indicates desperation and anger that comes from strong anxiety (it is not a pure rage which is usually expressed by ,chara $a f^{\prime}$ ). Another expression, "his face turned grey " (in Hebrew: "his countenance fell «), described Cain's reaction to the situation. An expression that someone "loses one's countenance" (lip corners and eyebrows are down) is a common indication of sadness, disappointment, and anger. Cain's reaction to being overlooked by God is the same as the reaction of a child whom his parents reject. This is frequently stated in the scripture of Tanakh itself (envy, cries, insistence, and hatred towards the accepted ones lead to an attempt to remove the enemy) (Gn 25,28; 27,34; 27,$41 ; 37,3-4 ; 37,11.18$.).

9 It's very likely that the dispute took place, because there was no heritage law. 
As soon as Cain got angry with his brother (Gn 4,5), his parents were supposed to act accordingly and quiet the situation. They were supposed to talk to the disappointed and confused child; they were supposed to offer care and support to free him from anger. However, they did not show any interest in Cain's feelings. Cain's parents are not even mentioned in this part of the text. God is the only one who is trying to calm him down. He speaks to Cain and takes the role of his loving mother. He tries to determine why Cain is unhappy: "Why are you angry, and why has your countenance fallen?« $(4,6)$

At the same time, God emphasizes that Cain still has a choice and shows him (just like in the book Deuteronomy) two possible paths (two ways of living): good or evil, life or death, life in God's presence or life without him.

\subsection{The first fratricide}

Tanakh describes the first fratricide very briefly: " >Now Cain said to his brother Abel: Let us go out to the field. And when they were in the field, Cain rose against his brother Abel, and killed him. « $(G n, 4,8)$ Cain had decided not to answer God when God asked him to choose one path of the two. Fighting God is way more complex than fighting a human, however. That is why he goes to his brother and talks to him (4,8a). The Hebrew script does not contain Cain's words addressed to Abel. It appears that something is missing in the manuscript (Dubovský 2008, 200).

Commentators are not able to find one common explanation for the missing words. Some think that God's words (Gn 4,7) eventually stopped Cain from talking to Abel, and he remained silent (which would indicate that a lack of communication can lead to murder) (Kaveh 2019). Others think that Cain had already spoken to Abel, and the author thought it was unnecessary to repeat his ideas and feelings. ${ }^{10}$ Another group of scholars supports the idea that the words were left out intentionally because Cain said something horrible. Another possible explanation seems to be that the author intentionally left out the words to create tension, or that this part of the script got lost when it was copied by hand, causing the transcriber to skip from one line to the end of the following line, which contained the same end-word (homoioteleuton) (Dubovský 2008, 200).

It seems that Cain originally had evil intentions and lured his brother to a distant place. Older translations of the script contain the expression: »let us go to the field" (Hebrew Samaritanus, Greek Septuaginta, Sirian Pešitto, Ramban); »come on, let us go outside« (some Aramean targumim) or »let us go outside« (Latin Vulgata). These translations indicate that the murder took place out in a field. The meaning of a field stands in opposition to a garden. A field is also a natural habitat of the serpent who "was craftier than any other wild animal« $(G n 3,1)$.

The fratricide is described in one sentence. A man encountered evil which resulted in the death of his brother. The script does not mention how Abel was killed. It happened in the fields, in a distant place where one would only call for help in

10 Ibn Ezra thinks that he repeated and appealed on Cain with previous words of God (Ibn Ezra, Bereshit $4,8)$. 
vain (compare Dt 22,25-27). It is a typical place for murder without witnesses. Maybe there was another reason (religious reason) for the choice of this place.

In Tanach's narrative, Cain behaves like an enthusiastic religious thinker who cannot agree that his brother brought a better offering to God (a firstborn cattle) and received God's favour. Cain thought that Abel intended to present God with a more excellent offering. Maybe he said to himself: I presented God with plants, which was not enough to win his favour. God liked the animal sacrifice presented by my brother better. I have to offer him something even more incredible than he did. What is better than a living creature? Maybe he would like a living human being; people of other nations regularly sacrifice humans. Could he offer more than his brother?

It may be possible (in connection to ideas of Baal religion) that »he thinks that spilt blood will give birth to a new generation, new strength (Žák 1990, 70). His brother's blood spilt in the field was an offering to God, and it was supposed to bless the soil. However, it resulted in the exact opposite because God did not want human life to be sacrificed for him (Beneš and Vad'ura 2010, 130). Cain became the first man who saw a man die (death caused by another man). In addition, Cain was the first human who became afraid of death $(\mathrm{Gn}, 4,14)$.

\subsection{Events after the murder}

God does not punish Cain immediately after the murder. Instead, God tries to talk to him calmly, just as if he is his loving and patient father. Again, God puts himself in a position where he takes on the role of a parent. He expects Cain to be sorry for what he did, confess his sin, take responsibility for the damage, and atone for his deed. God wants to know what happened: "Where is your brother Abel? « (Gn 4,9a). Cain, however, does not want to atone for his sin. His answer resembles the answer of a lying child. It seems that the way he answers to God is not appropriate. On the contrary, one would expect a more respectful response to the Almighty supreme being - he, unlike his parents, does not have experience with God's wrath.

Cain answers with a brief »/ do not know «. Therefore, Josephus assumes that Cain hid the dead body of his brother immediately after the act (Antiquitates Judaeorum I 2,1). After this, Cain adds: „Am I my brother's keeper?« (Gn 4,9b) (Ginzberg 2004) According to Wiesel:

„When God asks Cain: Where is your brother? Cain answers: ıl don't know. Am I my brother's keeper? ‘ From the point of view of Midrashim, it is possible to change punctuation which would result in an expression with a different meaning, such as $>1$ didn't know that I am supposed to be my brother's keeperı.« $(1994,42)$

Cain is trying to get rid of any responsibility for his brother. However, he answers that the first word: "I do not know! « betrays him (Prudký 2018, 246). His parents decided to accept death to gain knowledge. Adam was blessed with knowledge (his naked body, his wife, etc.). Another man - Cain, pretends that he does not know anything: „Even though it is obvious that he knows!« (247) 
Cain's reaction is horrible. Cain killed his unsuspecting brother just like a wolf kills sheep - the same sheep that Abel, his brother, took care of. As already mentioned, the name 'Cain' resembles the word ,kana' (the one who bought, received, created) and the derived word ,mikne' (herd). Cain's name implies that he is a brave and robust protector of herds. Cain, however, did not follow his destiny. The future of Israel is to protect the Pesach (Easter) lamb as its sons because the Paschal Lamb will save the lives of the firstborn sons of Israel and lead them to freedom. God educates the Israelites to treat each other as brothers and sisters who will not follow in Cain's footsteps.

The attempt to keep secrets from God is childish. God, however, does not give Cain another chance to confess. Now, he speaks to him as a strict father and a judge who is about to punish him: "What have you done? Listen! Your brother's blood cries out to me from the ground. « (Gn 4,10) Then God punishes Cain for what he did. It would be reasonable to expect a punishment by death: "Show no pity: life for life, eye for an eye, tooth for tooth, hand for hand, foot for foot. « (Dt 19,21; compare: Ex 21,12-24; Lv 24,17-20; Mt 5,38-42) Torah mentions that the punishment by death would be reasonable because Cain intentionally murdered his brother (Nu 35,16-21). Cain is, however, not punished by death. Many people think that it is not fair, while others respect and understand God's decision. Bereshit Rabbah $(22,26)$ states that $"$ He did not know that his blow would kill his brother«. Therefore, Cain did not commit murder; instead, he took someone's life, which was later punished by banishment (that is why God banished Cain from his homeland and did not kill him).

If we think about this killing as a murder, it is evident that many people want Cain to be punished by death. People feel this way mainly because they cannot relate to him in his original context when they read his words. However, let us look at the situation from the point of view of his mother. Cain is her son. He is now the only son that she has left. This changes the situation. Would his mother condemn him to death, or would she ask for mercy? She would probably ask for mercy and even lie just to protect her only son - just like the widow who lied and told her king an entirely made-up story:

"Your servant had two sons, and they fought with one another in the field; there was no one to part them, and one struck the other and killed him. Now the whole family has risen against your servant. They say, 'Give up the man who struck his brother, so that we may kill him for the life of his brother whom he murdered, even if we destroy the heir as well.' Thus they would quench my one remaining ember, and leave to my husband neither name nor remnant on the face of the earth. « (2 S 14,6-7)

The story of the widow, as was already mentioned, is entirely made up by Joab to save David's son. However, the feelings of the mother are honest. In the case of Cain, God considers the punishment from all aspects. He is not an unmerciful judge; he is like a loving mother who has just lost one child and, if he kills Cain, 
his mother will lose the only son she has left. God talks to Cain as if he were his parent (a loving mother and a merciful father). He represents the role of both parents that are not mentioned in this part of the scripture.

Cain will, however, receive a punishment. He is cursed (Gn 4,11a), according to Targum Onkelos (compare Bereishit Rabbah, Rashi), "more than soil«. He is banished from the land $(G)$. When he attempts to till the soil, it will no longer yield its produce to $\operatorname{him}^{11}(4,12 a)$. He becomes a fugitive $(4,12 b)$ rejected by his own family, "a wanderer on the earth «12 (Wiesel 1994, 47).

Cain's reaction to the punishment is: "My punishment is greater than I can bear. " $(G n 4,13)$ The statement does not carry a clear meaning in Hebrew. It can be interpreted in various ways, one of which is an expression of regret ("My sin is too great to ever be undone /.../ than God can forgive me« [LXX]) and contemplation of whether the evil act can be undone. On the other hand, God teaches humans that they can atone for their sins. Therefore, Cain can atone for his sin as well (Ramban, Bereishit 4,7). The punishment would lead Cain to realization and understanding that he has committed a horrible crime and that he cannot bear the guilt of this proportion (if Cain himself is the bearer of the guilt - see further below). There is also another interpretation: The crime is so horrible that there is no way to undo it (may insinuate: That is why I ask for the punishment by death), because God will never be able to forgive me (if the bearer of the guilt is God see further below).

Rabbi Eliezer Finkelman emphasizes that Cain's speech may be interpreted as a question even though it does not include a question mark, which is very common in Biblical Hebrew (Finkelman 2019).

,Avon' is a Hebrew word for ,crime', ,guilt for a crime' (Targum, Abravanel), and it can be translated as ,punishment for a crime' (Ibn Ezra Bereshit 4,13; Westerman 1984, 309; Torah y haftarot en versión Castellana). Some dictionaries, however, do not include this translation or even reject it (just like Abravanel). It may be because it is hard to understand that one word can mean ,crime', ,guilt' and ,punishment' for the crime as well. Ibn Ezra says that in the Hebraic Tanakh, ,avon' stands for ,crime/sin', ,guilt' and ,punishment' for a crime. He thinks that the translations as mentioned above of ,avon' cannot exist separately. If that is the case, Cain's reaction expresses terror, outrage, and surprise from the extent of the punishment ${ }^{13}$ (even though the punishment is too light for murder): "My punishment is more than I can bear (Gn 4,13)." (Finkelman 2019). Is Cain worried about his past (horrified by what he did) or his future (results of the punishment)? It is entirely possible that the author or editor of the script tried to express both aspects because the ambiguousness can be easily avoided. The author or the editor could have used a simple

11 Rashi claims that she is the reason why God sent an additional curse.

12 According to Midrashim, the greatest punishment for Cain was that he no longer knew what ,Shabbat' - Saturday meant.

13 Josephus Flavius believes that it was an expression through which he begged God not to be punished by death. 
word ,chataa' (sin) or ,onesh' (punishment, penalty), but instead he used a word that represents both - as if he were trying to draw attention to two choices that each human being has after committing such a terrible crime. The human individual will either be horrified by what he has done and will try to provide atonement, or he will be scared of the punishment, and he will try to hide from God.

The interpretation of ,avoni', which is translated as ,my punishment', corresponds to Cain's expected a much greater punishment. However, Cain managed to understand only half of what God told him. He understood that he had to leave the land (leave the soil alone) and that he now became a fugitive (Gn 4,14a,c). The rest of what God told him remained misunderstood. He thinks that he must also hide from God's face (4,14b). Therefore, he makes the same mistake as his parents after being banished from the Garden of Eden. Ramban thinks that the sentence "go out of the presence of God" means that he »is not allowed to be in God's presence by praying or offering a sacrifice« (Bereshit 4,14).

Cain decides to leave God's presence $(4,16)$. Cain also mistakenly thinks that anyone who will ever find him will try to kill him $(4,14 d)$. However, it is not clear who would want to kill him. He could be killed by God, another man, or an animal. God, however, did not punish him by death. Therefore, there is no reason for God killing Cain. Is it possible that another man would attempt to kill Cain? If we assume that the word, adam' stands for humankind created by God, people can punish him by death, but they do not have a supreme judge to make a decision. Besides, no law would put a sentence on Cain. Mrázek points out that "fratricide was not usually punished in ancient times because people did not know how to punish it " $(1989,32)$. If we assume that ,adam' stands for ,an individual', Cain could be killed (just as a rebellious son) only by his parents. Some rabbis emphasize the idea that Cain did not feel threatened by men or animals before the act. In most cases, they do not explain why he felt threatened after killing Abel. One group of rabbis think that after the murder, Cain was no longer perceived as an image of God (celem); therefore, he was left with his image (demut), and animals were no longer afraid of him - which is why he was scared they may kill him.

God does not attempt to explain how mistaken Cain is. As if He is tired of explaining the same thing to his parents. However, he explains the second misunderstanding: "Then the LORD said to him, >Not so! Whoever kills Cain will suffer a sevenfold vengeance. ( And the LORD put a mark on Cain, so that no one who came upon him would kill him. " $(\mathrm{Gn} 4,15)^{14}$ What is he trying to achieve by the sevenfold revenge? Cain's killer cannot be killed seven times. If there are other people, six of Cain's relatives or offspring may die along with him. Some rabbis say that it is not a seven times greater punishment, but only a figurative way of expressing that the punishment will be significant since the number seven represents completeness (Radak, Bereishit 4,15). Other rabbis (Rashi, Ibn Ezra) believe, just as is written in Targum Onkelos that it has nothing to do with the extent of the punishment but rather connected to the time of the punishment (Flavius Jo-

14 The same motif is repeated in Christian tradition. 
sephus, Antiquitates Judaeorum I 2,1). The punishment will affect the Seventh Generation of Adam (or Seventh Generation of Cain, i.e., Tubal-Cain. It would mean that Cain was not given mercy. Frequently, number seven represents an end (or culmination) of an era.

Just like Cain's parents were given clothes by God $(\mathrm{Gn} 3,21)$ to protect them and remind them of their sin, Cain was given protection, and he would carry a reminiscence of his guilt as well. God marks ${ }^{15}$ Cain: " Then the Lord put a mark on Cain so that no one who found him would kill him « $(4,15)$. Torah does not explain how the mark was placed on Cain. Hebrew script uses the verb ,to place', which is interpreted as carve, cut out, or painted by ink. The script does not mention the exact location of the mark. When we consider the ideas written in the Book of Ezekiel: „Who had the writing case at his side« (Ez 9,3), a mark is usually placed on the forehead, some scholars believe that the mark was a cutting located on Cain's arm (Pirke Rabbi Eliezer 21). Slaves, soldiers, and people in servitude were marked in the same way (Prudký 2018, 251). According to Kohler, Bennett, and Ginzberg, opinions on what the mark looked like vary. Nevertheless, the most common concept is that Cain suffered from a disease, and its symptoms were visible on his appearance, writing or reading, seal, horn, a sign of acceptance, or on Cain's dog.

Cain left God's presence (literally »went out of the presence of God «). He was homeless. The result of Cain's act is a decay of soil. God cursed the land he cultivated after his parents had sinned; however, he is the one who caused a complete decay of the already cursed soil by spilling innocent blood on it, and it seems that it would not make any difference if the blood spilt on the soil came from a magic ritual or an intentional murder. The soil that drank his brother's blood will not provide Cain with any more products, and he is banished from it.

Cain's story resembles the story of his parents. Cain's parents, as well as Cain himself: 1 . Were warned before sinning; 2 . They disobeyed God and sinned; 3. God allows them to confess. He asks the man: "Where are you? « $(G n 3,9)$; he asks the woman: "What is this you have done? $(3,13)$ He asks Cain: "Where is your brother Abel? « $(4,9) ;$ "What have you done? « $(4,10) ; 4$. An evil act is followed by the curse (of serpent and soil) $(3 ; 14,7)$; of Cain $(4,11) ; 5$. Sinners are banished from their home, and they must seek refuge $(4,14) ; 6$. They want to be close ${ }^{16}$ to God.

Moshe Kaveh points out that even though these stories share similar characteristics, they differ in many aspects: 1 . The sin of Adam and Eve is against God himself; Cain's sin is linked to humankind; 2. Cain's parents confess (even though they try to blame someone else), but Cain refuses to admit his crime (Kaveh 2019).

15 Exile cities and edges of altars will be marked with the same mark as mentioned here. The mark should prevent killing and never-ending avenge.

16 Adam and Eve wanted to be similar to God and be even closer to him, but at last they became dust and they were banished from the Garden. Cain wanted to be like his father and serve the soil but instead, he became a wanderer. He attempted to make a great offering to God who punished him for it. 


\section{Conclusion}

Humans are presented with a choice between knowledge and death in the Garden of Eden. They choose death. The serpent's attempt to threaten the human's life was flourishing. The human being rebels against the Creator is alienated from Him and participates personally and institutionally in producing oppressive behaviour and structures that further alienate humans from one another (Žalec and Pavlikova 2019, 39-48; 2019, 1015-1026). This leads to a loss of human dignity as human persons turn against each other in acts of injustice, violence, and cruelty (Bernaciak 2018, 25-26). This is not the last sin of humanity (sin leads to another sin). From a lie (Eve lied about what God told her about the forbidden fruit), Sin grows more significant to fratricide and murder. The first murder takes place. Humankind saw the difference between good and evil. Humanity is always taught to choose the good but fails to do so and chooses death instead. The concept of murder is presented by the conflict between settled and nomadic lifestyles. It may be a hidden criticism of a king who thinks that he holds control over life itself, including his subjects' lives or deaths (even lifestyles). In addition, these texts imply the dangers stemming from idolatrous cults and pseudo-religious ideologies that rebel against the natural order of creation. ${ }^{17}$

Torah presents the idea that every human being (not only a ruler) is capable of this horrible act and adds that there are several types of killing: intentional murder, unintentional killing, killing in a battle, and execution of a criminal. On the other hand, Torah does not accept the concept of manslaughter because 1 . The only supreme being is God, never a human ruler; 2 . All men are created in the image of God; therefore, when a human is attacked, it is as if God were attacked as well; 3 . The value that should be protected the most by humans is one's life and the life of another human being (some rabbis include the lives of other living beings as well); 4. It is a natural right shared by all humans to live in their community; this, however, no longer applies after committing a sin that Torah established as punishable by death; 5 . Even if a human carries a burden of his accentor's sins, he/she always should choose life and live in the presence of God; they should not choose death or a curse; 6 . A human being who made a mistake in a hardship still has a chance for atonement.

A human (or a sovereign ruler) who disobeys one of the commandments written in the Torah finds himself in conflict with another human being as well as a community (whose laws he violated). Moreover, each time he/she gets into a conflict, this conflict is ultimate with God. A sinner is cut off from the presence of God, and he/ she is punished by banishment (either to the Land of Nod or ,Sheol'). By not obeying the commandments written in the Torah (,chukim cadikim' in Dt 4,8), such a human being is cut off from the presence of the righteous God of Israel and finds himself/ herself in a state of deep alienation and lack of fulfilment. On the other hand, obe-

17 In modern times, "the dangers of the naturalistic tendencies within the modern sciences " became evident in the post-enlightenment ideologies of »Hitlerism and /.../ Bolshevism«, as Valčo (et al.) rightly observe $(2019,176)$. 
dience to Scriptural commandments (both moral and cultic) "teaches us to correctly answer God's calling so that [one] can fulfil one's ultimate purpose " of being a good creature of God in His good creation (Petro 2018, 45).

\section{References}

Abraham Ben Isaiah, Benjamin Sharfman. 1977. The Pentateuch and Rashi's Commentary: A Linear Translation Into English Leviticus. Brooklyn: Publishing Company.

Abraham Ibn Ezra. [n.d.]. Ibn Ezra's Torah Commentary. AlTorah. http://mg.alhatorah.org/ Dual/Ibn_Ezra_First_Commentary/1.1\#t1e0n6 (accessed 20. 1. 2018).

Albeck, Chanoch, and Julius Theodor. 1965. Midrash Bereshit Rabba. Critical Edition with Notes and Commentary. Jerusalem: Wahrmann Books.

Alter, Robert. 1981. The Art of Biblical Narrative. New York: Basic Books.

- - . 1990. The Hebrew Bible: A Translation with Commentary. New York: WW Norton \& Co.

Beneš, Jiří, and Petr Vad'ura. 2010. Pradějiny. Prague: Kalich.

Bernaciak, Juraj. 2018. Dôstojnost' človeka, ako subjektu, pre realizáciu spravodlivosti a lásky, vo svetle vyjadrení niektorých teológov a sociológov v XX. storočí a na začiatku XXI. storočia. Theologos 20, no. 1:25-51.

Bible, Písmo svaté Starého a Nového zákona včetně deuterokanonických knih. 1991. Český ekumenický překlad. Prague: Zvon.

Bič, Miloš, ed. 1978. Starý zákon: Překlad s výkladem I.: Genesis. Prague: Kalich.

Drazin, Israel. 2014. An Unusual Interpretation of Cain and Abel's Sacrifice. Books and Thoughts, 22. 6. https://booksnthoughts.com/an-unusual-interpretation-of-cain-and-abels-sacrifice/ (accessed 12. 8. 2019).

Dubovský, Peter, ed. 2008. Genezis: Komentár k Starému zákonu I. Trnava: Dobrá kniha.

Elliger, Karl, and Wilhelm Rudolph, eds. 1990. Torah Neviim Uchtuvim: Biblia Hebraica Stuttgartensia. Editio Funditus Renovata. Stuttgart: Deutsche Bibelgesellschaft.

Finkelman, Eliezer. 2019. Cain's (Im) Penitent Response to his Punishment. The Torah. http:// thetorah.com/cains-im-penitent-response-tohis-punishment/ (accessed 17. 7. 2019).

Ganzfried, Shlomo. 2012. Kicur šulchan aruch. Agadah: Těšín.

Ginzberg, Louis. 2004. The Legends of the Jews. Montana: Kessinger Publishing.
Goldschmidt, Lazarus, ed. 1929-1936. Der Babylonische Talmud. Berlin: Verlag Biblion.

Gunkel, Hermann. 1963. Genesis. Göttinger Handkommentar zum Alten Testament. Göttingen: Vandenhoeck and Ruprecht.

Hirsch, Chumash. 2002. The Hirsch Chumash: Sefer Bereshis. Jerusalem/New York: Feldheim Publishers, Judaica Press.

Hirsch, Isidor, and Gustav Sicher, eds. 1932. Chamiša chumšej Tora: Pět knih Mojžíšových. Prague: Svaz pražských náboženských obcí židovských.

Jeruzalémská bible 1: Geneze. 1992. Prague: Krystal OP Nakladatelství dobré teologie.

Kardis, Mária. 2019. The Presence of God - Certainty or Uncertainty? Religious Experience in the Biblical Tradition. Theologos 21, no. 1:121129.

Kaveh, Moshe. 2019. Lasting Lessons from the First Family: Parashat Bereshit 5766. Bar Ilan University. https://www.biu.ac.il/JH/Parasha/eng/ bereshit/ kav1.html (accessed 15. 8. 2019).

Kocáková, Marianna. 2018. Motivácia k náboženskej činnosti - exkurz do psychológie náboženstva. Theologos 20, no. 1:208-215.

Kohler, Kaufmann, William H. Bennett, and Louis Ginzberg. 1901-1906. Jewish Encyclopedia. 12. vols. London: [s.n.]. http://www.jewishencyclopedia.com (accessed 16. 8. 2019).

Landau, Dov. 2019. But to Cain and His Offering He Paid no Heed. Parashat Bereshit 5765. Bar Ilan University. https://www.biu.ac.il/JH/Parasha/ eng/bereshit/lan.html (accessed 20. 8. 2019).

Leibowitz, Nehama. 2004. New Studies in Bereshit (Genesis): In the Context of Ancient and Modern Jewish Bible Commentary. Jerusalem: Hemed Press.

Mandelkern, Salomon, and Solomon Aadelkern. 1937. Veteris Testamenti Concordantiae Hebraicae atque Chaldaicae. New York: Sumptibus Schocken.

McCurdy, Frederic, Kaufmann Kohler, Louis Ginzberg, and Richard Gottheil. 2019. Abel. Jewish Encyclopaedia. http://www.jewishencyclopedia.com/articles/216abel?fb_comment_id=10150430725658594_28189762 (accessed 12. 8. 2019). 
Midrash Rabbah. 1938. London: Soncino.

Mikraot gedolot: Hamishah humshe Torah im Targum Onkelos veim shenayim vearbaim perushim 1-5. 1912.Vilna: Ram.

Mishnah: A New Translation with a Commentary by Rabbi Pinehas Kehati. 1994. Jeruzalem: Eliner Library.

Mrázek, Milan. 1989. Genesis 1-11. Prague: Synodní rada Českobratrské církve evangelické.

Neusner, Jacob, ed. 1988. The Mishnah: A New Translation. London: Yale University Press.

Pavlikova, Martina, and Bojan Žalec. 2019. Boj za človekov jaz in pristnost: Kierkegaardova kritika javnosti, uveljavljenega reda, medijev in lažnega krščanstva. Bogoslovni Vestnik 79, no. 4:1015-1026.

Peschke, Karl-Heinz. 1999. Křestanská etika. Prague: Vyšehrad.

Pět knih Mojžíšových včetně haftarot s českým překladem rabína Efraima Sidona. 2012. Prague: Sefer.

Petro, Marek. 2018. Človek - Boží obraz. Theologos 20, no. 2:45-54.

Pirkej avot. Výroky otců: Traktát Babylónského talmudu s paralelním českým překladem a komentářem. 1994. Prague: Sefer.

Prudký, Martin. 2018. Genesis I (1,1-6,8): Český ekumenický komentár ke Starému zákonu 1. Prague: Centrum biblických studií AV ČR a UK.

Rahlfs, Alfred, ed. 1975. Septuaginta. Edition minor. Stuttgart: German Bible Society.

Roubalová, M., Roman Králik, Daniel Slivka, and Igor Tavilla. 2018. Význam přinášení prvotin půdy do jeruzalémského chrámu: Historicko-teologická perspektiva. Historica Ecclesiastica 9, no. 1:3-13.

Skolnik, Fred, in Michael Berenbaum, eds. 2007. Encyclopedia Judaica. 16. vols. Jerusalem Keter Publishing House.

Sládek, Pavel. 2008. Malá encyklopedie rabínského judaismu. Prague: Libri.

Slivka, Daniel. 2018. Jeruzalemský Talmud a jeho význam v judaizme. Theologos 20, no. 2:37-44.

Šoltés, Radovan. 2018. Vzdelanie a výchova $\mathrm{k}$ sociálnemu cíteniu ako neustály zápas medzi hladaním spravodlivosti a konfrontáciou sa s l'udskou hriešnost́ou podl'a sociálnej náuky Cirkvi. Theologos 20, no. 1:81-90.
Targum Onkelos. [n.d.]. Jeruzalem: Mamra. http:// www.mechon-mamre.org/i/t/u/u0.htm (accessed 20. 1. 2018).

The Schottenstein Daf Yomi Edition Talmud Bavli. 1997. New York: Menorah Publications.

Tirpák, Peter. 2018. Význam náboženského putovania v živote Cirkvi. Theologos 20, no. 1:9198.

Torah y haftarot en versión Castellana. [n.d.]. Jumash Bereshit. https://www.masuah.org/ Jumash/capitulos_tabla.htm (accessed 10. 3. 2019)

Valčo, Michal, Katarína Valčová, Kamil Kardis, and Daniel Slivka. 2019. Prorocka kritika Samuela Stefana Osuskeho proti Hitlerizmu, Fasizmu a Vojne. Historia Ecclesiastica 20, no. 2:176-192.

Valčo, Michal, Peter Šturák, Katarína Valčová, Ján Zozulak and Ioan Duram. 2019. Socialny Trinitarianizmus vo svetle Lutherovych Dorazov v Uceni o Trojici. Historia Ecclesiastica 10, no. 1:176-192.

Von Rad, Gerhard. 1972. Genesis. London: SCM Press.

Werblowsky, Zwi, and Geoffrey Wigoder. 1966. The Encyclopedia of the Jewish Religion. Holt: Rinehart and Winston.

Westerman, Claus. 1984. Genesis 1-11: A Commentary. Minneapolis: Augsburg.

- - - 1987. Tisíc let a jeden den. Prague: Kalich.

Wiesel, Elie. 1994. Bible: Postavy a príběhy. Prague: Sefer.

Zozulak, Jan, and Michal Valčo. 2018. Byzantine philosophy of the person and its theological implications. Bogoslovni Vestnik 78, no. 1:1037-1049

Žák, Vladislav. 1990. Na počátku: Výklad knihy Genesis. Prague: Evangelická církev metodistická.

Žalec, Bojan, and Martina Pavlikova. 2019. Religious tolerance and intolerance. European Journal of Science and Theology 15, no. 5:39-48. 